\section{Soil respiration and carbon balance in a Moso bamboo (Phyllostachys heterocycla (Carr.) Mitford cV. Pubescens) forest in subtropical China}

\author{
Xiaolu Tang ${ }^{(1-2)}$, Shaohui Fan ${ }^{(1)}$, Lianghua $Q i^{(1)}$, Fengying Guan ${ }^{(1)}$, Chunju \\ $\mathrm{Cai}^{(1)}$, Manyi Du ${ }^{(1)}$
}

Understanding spatial and temporal variation in soil respiration (RS) in different forest ecosystems is crucial to estimate the global carbon balance. Bamboo forest is a special forest type in southern China covering an area of $\mathbf{5 . 3 8}$ million ha, $70 \%$ of which are Moso bamboo (Phyllostachys heterocycla (Carr.) Mitford cv. Pubescens) forests. Bamboo forests contribute more than $10 \%$ to the whole carbon stock of forest ecosystems in China, and therefore play a critical role in the regional and national carbon balance. However, little information on the seasonal dynamic of RS and the carbon balance of Moso bamboo forests is available. In this study, litter removal and trenching methods were applied to partition RS into root respiration (RR), litter respiration (RL) and soil organic matter derived respiration (RM), and to study their seasonal dynamics and carbon balance in a pure Moso bamboo forest. Monthly RS, its source components and combined monthly environmental factors were measured. RS and its source components showed a significant seasonal variability with higher values from June to August and lower values from December to February driven by soil temperature and moisture $(P<0.001)$. Annual average $R S, R R, R L$ and RM were $2.37,0.69,0.58$ and $1.10 \mu \mathrm{mol} \mathrm{m} \mathrm{m}^{-2} \mathrm{~s}^{-1}$ with $Q_{10}$ values of $1.25,1.15$, 1.19 and 1.26, respectively. Annual RS was $8.97 \mathrm{t} \mathrm{C} \mathrm{ha}^{-1}$, and RR, RL and RM contributed $29 \%, 22 \%$ and $49 \%$, respectively. Annual NEP was $4.72 \mathrm{t} \mathrm{C} \mathrm{ha}^{-1} \mathrm{y}^{-1}$, indicating that the Moso bamboo forest studied is a significant carbon sink.

Keywords: Soil Respiration, Source Components, Soil Temperature, Soil Moisture, Net Ecosystem Production

\begin{abstract}
Introduction
Forest ecosystems can be carbon sinks or sources depending on the balance between carbon input through photosynthesis and release from respiration (Saiz et al. 2006). In forest ecosystems, soil respiration (RS) can account for $30 \%$ to $80 \%$ of the whole ecosystem respiration (Davidson et al. 2000, Law et al. 2002, Davidson \& Janssens 2006). Globally, RS is the second largest carbon exchange between the soil and atmosphere, and returns as much as 80 to 98
\end{abstract}

Pg C yr ${ }^{-1}$ back into the atmosphere (BondLamberty \& Thomson 2010, Raich et al. 2002), which is more than 10 times the carbon release from fossil fuel combustion (IPCC 2007). Therefore, RS is one of the major contributors to the carbon balance, and small changes in RS rate could give rise to significant changes in atmospheric $\mathrm{CO}_{2}$ concentration, leading to feedbacks to climate change (Ryan \& Law 2005). Although the significance of RS for carbon balance on a regional and even the global scale has been

(1) Key Laboratory of Bamboo and Rattan Science, International Centre for Bamboo and Rattan, 100102 Wangjing, Chaoyang District, Beijing (China); (2) Department of Forest Inventory and Remote Sensing, Burckhardt Institute, Georg-August-Universität Göttingen, 37077 Göttingen (Germany)

@ Shaohui Fan (lxtt2010@163.com)

Received: May 24, 2014 - Accepted: Oct 18, 2014

Citation: Tang X, Fan S, Qi L, Guan F, Cai C, Du M, 2015. Soil respiration and carbon balance in a Moso bamboo (Phyllostachys heterocycla (Carr.) Mitford cv. Pubescens) forest in subtropical China. iForest 8: 606-614 [online 2015-02-02] URL: http://www.sisef.it/iforest/ contents/?id=ifor1360-007

Communicated by: Silvano Fares demonstrated, there is still much to understand about biotic or abiotic controllers of RS and its source components (Gomez-Casanovas et al. 2012). For example, partitioning $\mathrm{RS}$ is still challenging because of remarkable soil disturbances (Hanson et al. 2000, Tang et al. 2005). Spatial and temporal variability in RS are often reported due to high variations in forest types, stand ages and management practices (King et al. 2004, Tang \& Baldocchi 2005, Saiz et al. 2006, Wang et al. 2006, Pang et al. 2013). This has limited our ability to accurately predict the responses of RS and carbon balance to current and future climate change (Ryan \& Law 2005). Therefore, measuring RS in different forest types has been proven to be increasingly important to accurately predict global carbon cycles and its responses to climate change (Wang et al. 2006).

RS is overwhelmingly comprised of rhizoshperic respiration (respiration from roots, mycorrhizae and microbial respiration in the rhizosphere) and heterotrophic respiration (respiration by microbial organisms and soil fauna - Bond-Lamberty et al. 2004, Wang \& Yang 2007). Quantifying RS and the contributions of its components are essential to understand and model global carbon cycling (Wang \& Yang 2007). However, partitioning RS is still difficult (Hanson et al. 2000). Attempts have been done to partition RS using different approaches, such as component integration by removing roots directly from the soil (Edwards \& Sollins 1973), isotopic signal detection techniques (Kuzyakov 2006), root exclusion by trenching in a subplot to prevent root ingrowth and eliminating root growth and respiration (Hanson et al. 2000). Trenching is the approach more widely used in forest ecosystems (Hanson et al. 2000). However, trenching increases the residual decomposition of remaining roots (Lee et al. 2003), increases soil moisture due to the absence of water uptake by roots in trenched plots (Hanson et al. 2000) and may change substrate supply for microbial respiration and microbial populations (Högberg \& Högberg 2002, Lee et al. 2003). The artificially introduced bias or modifications in the trenching plots must be quantified in order to precisely estimate the carbon cycle in forest ecosystems (Subke et al. 2006).

Soil temperature and moisture are the main controllers of RS and have received great attentions (Davidson et al. 1998, Rey et al. 2002). The relationships between RS and soil temperature are generally modeled as exponential functions (Saiz et al. 2006, Yan et al. 2006). In contrast, equations used to model the relationship between RS and soil moisture either assume asymptotic RS values for high soil moisture or a maximum RS at an optimized soil moisture (Davidson et al. 2000, Epron et al. 2004). However, strong 
variability in RS does not correlate with soil temperature or moisture in a predicable manner (Wan et al. 2002, Tang \& Baldocchi 2005). For example, some researchers conclude that soil moisture has significant ef fects on RS (Rey et al. 2002, Suseela et al. 2012), while others report only minimal effects (Raich et al. 2002) or no effect at all (Pang et al. 2013). Biological drivers, such as photosynthesis, have been recognized as key drivers of rhizospheric respiration (Janssens et al. 2001, Kuzyakov \& Gavrichkova 2010). However, the fact has been overlooked in most RS studies because RS is highly related with soil temperature or water content, which could mask the direct effects of photosynthesis on RS (Kuzyakov \& Gavrichkova 2010). Therefore, it is still unclear how the relationships between RS components change with environmental factors, biological drivers and vegetation types, and obviously more measurement data on RS components from across various climate zones and different vegetation types are required to improve our understanding of RS and its components (Boone et al. 1998).

Bamboo forest is an important forest type in southern China and has expanded very rapidly in recent decades. According to the seventh National Forest Inventory data, bamboo forest covered an area of 5.38 million hectares in 2009 with an increasing trend, $70 \%$ of which was Moso bamboo forests ( Jia et al. 2009). The carbon stock in bamboo forests contributes by more than $10 \%$ of the carbon stock in forest ecosystems in China (Chen et al. 2009). Thus, bamboo forests play a critical role in the regional, national, and even global carbon balance ( $\mathrm{Tu}$ et al. 2013). Two recent publications have been done on RS in Moso bamboo forest (Xiao et al. 2010, Liu et al. 2011), however they applied different methods to measure RS which makes comparisons difficult. Quantifying RS and its source components in Moso bamboo forest is critical for evaluating the

Tab. 1 - Main characteristics of the plots in the investigated Moso bamboo forest in Chibi city from April 2011 to March 2012.

\begin{tabular}{lc}
\hline Variable & Values \\
\hline Average elevation $(\mathrm{m})$ & 161 \\
Slope $\left(^{\circ}\right)$ & 16 \\
Average height $(\mathrm{m})$ & 11.1 \\
Average Diameter $(\mathrm{cm})$ & 8.2 \\
Average density $\left(\mathrm{stems} \mathrm{ha}^{-1}\right)$ & 2908 \\
Soil bulk density $\left(\mathrm{g} \mathrm{cm}^{-3}\right)$ & 1.28 \\
Total porosity $(\%)$ & 45.21 \\
Root depth $(\mathrm{cm})$ & $0-40$ \\
SOM content $\left(\mathrm{g} \mathrm{kg}^{-1}\right)$ & 26.41 \\
Total N $\left(\mathrm{g} \mathrm{kg}^{-1}\right)$ & 1.33 \\
Total K $\left(\mathrm{g} \mathrm{kg}^{-1}\right)$ & 9.68 \\
Available K $\left(\mathrm{mg} \mathrm{kg}^{-1}\right)$ & 58.77 \\
Total P $\left(\mathrm{g} \mathrm{kg}^{-1}\right)$ & 0.32 \\
Available P $\left(\mathrm{mg} \mathrm{kg}^{-1}\right)$ & 11.68 \\
\hline
\end{tabular}

role of these forests in carbon cycling and climatic systems.

The objectives of this study were: (1) to evaluate seasonal dynamics of RS and its source components; (2) to qualify the contributions of source components to total RS; (3) to evaluate the relationship between RS, its source components and environmental factors; and (4) to assess whether Moso bamboo forest could act as a carbon sink or source under climate change.

\section{Materials and methods}

\section{Site description}

The experimental site is located in Dingmushan forest station in Chibi city $\left(29^{\circ} 28^{\prime}\right.$ to $29^{\circ} 55^{\prime} \mathrm{N}, 113^{\circ} 32^{\prime}$ to $114^{\circ} 13^{\prime} \mathrm{E}$ ), Hubei province, China. This area has a typical subtropical monsoon climate. The average precipitation is $1251-1608 \mathrm{~mm} \mathrm{yr}^{-1}$, mainly distributed between May and August (accounting for $51.5 \%$ of the total rainfall). The maximum precipitation was $2678 \mathrm{~mm}$ in 1954 and minimum precipitation was 910 $\mathrm{mm}$ in 1968. The mean annual temperature is $16.9{ }^{\circ} \mathrm{C}$ with the highest temperature in July and the lowest temperature in January. The number of frost free days is 247-261.

The Moso bamboo forests were planted in the 1960s in China, and most are currently pure bamboo forests with small shrubs and herbs, and understory species such as Lirildendron chinense Hemsl., Rhus chinensis Mill., Loropetalum Chinense (R. Br.) Oliv., Smilax glabra Roxb., Castanea seguinii Dode., Castanopsis tibetana Hance and $\mathrm{Ca}$ stanopsis tessellata Hick. et A. Camus, etc. More details of the site conditions and soil characteristics are shown in Tab. 1 .

\section{Experimental design}

In March 2011, three $20 \times 20 \mathrm{~m}$ plots (representing the average conditions of bamboo growth in the area in terms of slope, density and soil depth) were established in an unmanaged Moso bamboo forest. The distance between each plot was less than $1 \mathrm{~km}$, which avoided differences in climate and soil types. In each plot, 10 transparent polyvinyl chloride collars (PVC, $20 \mathrm{~cm}$ inside diameter, 12 $\mathrm{cm}$ in height) were inserted into the soil at a depth of $3 \mathrm{~cm}$ ( $\mathrm{Li}$ et al. 2010). Once installed, collars were not moved all over the study period. The collars were divided into three groups: intact soil (IS), litter-free soil (LS) and trenched soil (TS).

Firstly, four collars were inserted $5 \mathrm{~m}$ away from the plot center along a diagonal transect into IS to measure the total RS. Secondly, $50 \mathrm{~cm}$ apart from IS collars, litter was removed from the soil surface $(25 \mathrm{~cm}$ radius circle) and four collars were inserted into LS. The $\mathrm{CO}_{2}$ flux measured on LS was considered as RS without $\mathrm{CO}_{2}$ flux derived from the litter. This litter-free RS was defi- ned as RC. The difference between RS and $\mathrm{RC}$ was considered to be litter respiration $(\mathrm{RL}): \mathrm{RL}=\mathrm{RS}-\mathrm{RC}$.

Third, trenching was performed in early March 2011. In each plot center, a subplot with a size of $80 \times 80 \mathrm{~cm}$ was established and trenched to a depth of $80 \mathrm{~cm}$. After that, vegetation and litter were removed with care to minimize soil disturbance, and the subplots were kept free of live vegetation and litter throughout the study period. Since most of the bamboo roots were distributed within $40 \mathrm{~cm}$ of the surface, trenching to 80 $\mathrm{cm}$ was sufficient to achieve the objectives of this research. Polyethylene boards with a thickness of $0.5 \mathrm{~cm}$ were inserted into the trenches vertically to prevent root ingrowth after trenching. The $\mathrm{CO}_{2}$ flux from these trenched subplots was considered as the $\mathrm{CO}_{2}$ flux derived from the soil organic matter (RM). Therefore, root respiration (RR) could be calculated as $\mathrm{RR}=\mathrm{RC}-\mathrm{RM}$.

\section{$R S$, soil temperature and soil moisture measurements}

Four weeks after trenching, RS was measured using a LI-Cor-8100 (Li-Cor Inc., Lincoln, NE, USA) automated soil $\mathrm{CO}_{2}$ flux system from April 2011 to March 2012. The soil $\mathrm{CO}_{2}$ efflux was calculated based on a linear increase in chamber $\mathrm{CO}_{2}$ concentrations over time. The RS was expressed by $\mu \mathrm{mol} \mathrm{m} \mathrm{m}^{-2} \mathrm{~s}^{-1}$. Measurements were carried out between 9:00 a.m. and 12:00 a.m. because the respiration rate during that period represents the diurnal average (Wang et al. 2011). RS in rainy days was not measured. Soil temperature and moisture near the collars at a depth of $5 \mathrm{~cm}$ were measured using the soil temperature and moisture sensors of the LICor- 8100 while measuring the $\mathrm{CO}_{2}$ flux over the entire study period.

\section{Carbon stock in bamboo}

In May 2011, bamboos with a diameter at breast height $(\mathrm{DBH}, \mathrm{cm})$ larger than $5 \mathrm{~cm}$ were measured (only bamboos larger than 5 $\mathrm{cm}$ were accounted in carbon stock estimation - Zhou 2006). The aboveground biomass of individual bamboo stems was estimated using the eqn. 1 reported below (Zhou et al. 2010). For simplicity, 0.5 was used as carbon concentration to convert biomass to carbon (Zhou \& Jiang 2004). The belowground carbon was measured by the ratio 0.2 of aboveground/belowground carbon stock (China Green Foundation 2008 - eqn. 1).

$$
\begin{aligned}
A G B & =747.784 \cdot D B H^{2.771} . \\
& \cdot\left(\frac{0.148 \cdot A}{0.028+A}\right)^{5.555}+3.772
\end{aligned}
$$

where $A$ is the age expressed in du (Zhou et al. 2010). One "du" stands for 1-2 years, and therefore 2, 3 and 4 "du" correspond age $3-4,5-6$ and 7-8 years, respectively. 

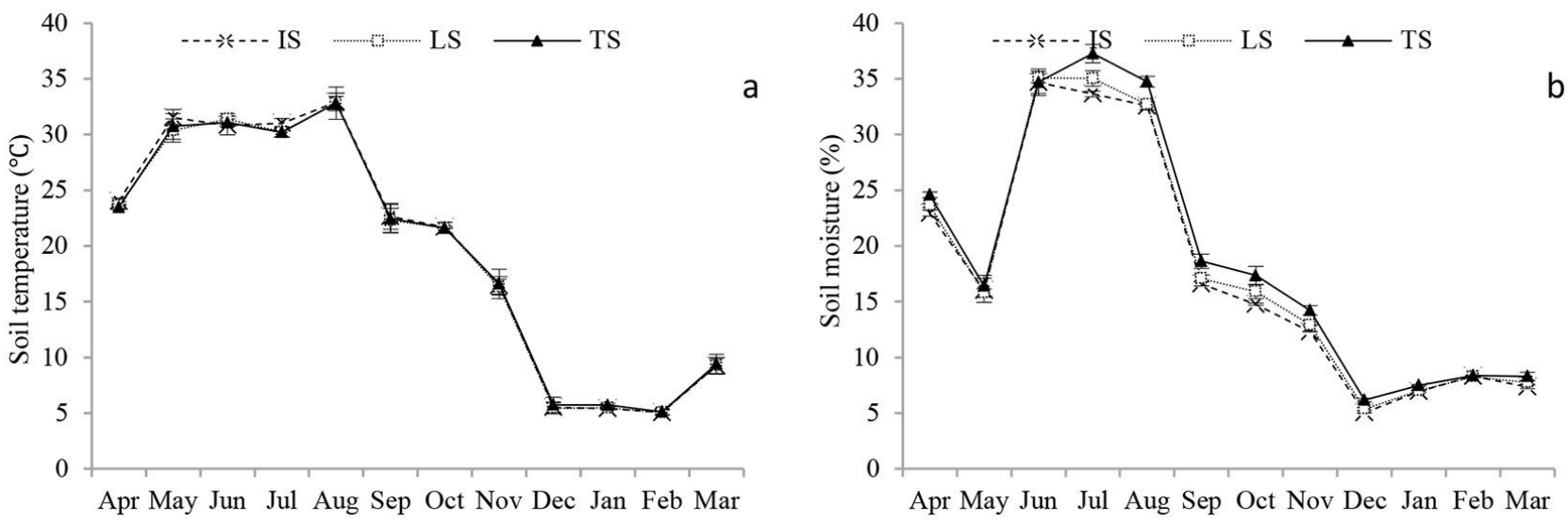

Fig. 1 - Seasonal changes of (a) soil temperature $\left(\mathrm{T},{ }^{\circ} \mathrm{C}\right)$ and (b) soil moisture $(\mathrm{W}, \%)$ at depth of $5 \mathrm{~cm}$ in the Moso bamboo forest in Chibi city from April 2011 to March 2012. IS, LS and TS represent intact soil, litter-free soil and trenched soil, respectively. Error bars represent the standard error $(n=3)$.

\section{Carbon stock in understory and litter}

Understory was harvested by uprooting in three $1 \times 1 \mathrm{~m}$ subplots in each plot. All samples were washed in floating water. Monthly litter input was collected by $1 \times 1 \mathrm{~m}$ collectors $(\mathrm{n}=3)$ for each plot. All understory samples and litter were dried to constant weight at $65{ }^{\circ} \mathrm{C}$. The subplots for understory and collectors for litter input were set in a similar equilateral triangle shape in each plot. The carbon concentration to convert biomass to carbon was assumed to be 0.5 . Since most of understory species were annual plants, the standing stock was used to represent the annual growth.

\section{Data analysis and modeling annual RS}

Data analysis was conducted using the software package SPSS ${ }^{\circledR}$ v.16.0 and Microsoft Excel $^{\circledR}$ 2003. First, RS, soil temperature and moisture from four collars (two collars for RM) were averaged over each plot. Repeated measures analysis of variance (RM ANOVA) and least significant difference (LSD) were applied to test the seasonality of RS, soil temperature and moisture with $\alpha=0.05$. Regression analysis was used to model the relationships between respiration rates and soil temperature and moisture. Standard errors were calculated over the 3 plots considered and represent the spatial variation in respiration rates among plots. Both one-factor and two-factor models were conducted to model the relationship between RS and soil temperature and moisture ( $\mathrm{Li}$ et al. 2008 eqn. 2 , eqn. 3 , eqn. 4 ):

$$
\begin{gathered}
R S=a e^{b T} \\
R S=a W+b \\
R S=a W T+b
\end{gathered}
$$

where $R S$ is the measured monthly RS rate or its component respiration rates $\left(\mu \mathrm{mol} \mathrm{m} \mathrm{m}^{-2}\right.$ $\left.\mathrm{s}^{-1}\right), T\left({ }^{\circ} \mathrm{C}\right)$ and $W(\%)$ are the measured soil temperature and moisture at $5 \mathrm{~cm}$ depth, re- spectively, and $a, b$ and $c$ are the fitting parameters.

Temperature sensitivity $\left(Q_{10}\right)$, which is related to the increase of RS rate at $10{ }^{\circ} \mathrm{C}$ intervals, was calculated as $\mathrm{RS}_{\mathrm{T}+10} / \mathrm{RS}_{\mathrm{T}} ; \mathrm{RS}_{\mathrm{T}}$ is a regression model in the form of eqn. 2 or eqn. 4 related soil temperature. In most cases, $Q_{10}$ was derived from a one-factor regression model (eqn. 3 - Davidson et al. 2006b, Rey et al. 2002). However, the onefactor regression model could not well reveal the RS and soil temperature, and the $Q_{10}$ changed with soil temperature and soil moisture (Davidson \& Janssens 2006). Therefore, a two-factor regression model were developed to estimate $Q_{10}$ (eqn. 5):

$$
Q_{10}=\frac{a W(T+10)+b}{a W T+b}=1+\frac{10 a W}{a W T+b}
$$

where $a$ and $b$ were taken from eqn. 4 .

\section{Net ecosystem production (NEP)}

The annual carbon flux of RS and source components were calculated as follows (eqn. 6):

$$
R_{A}=\sum_{i=1}^{12} R_{i} \cdot 10^{-6} \cdot \frac{12}{44} \cdot 44 \cdot 3600 \cdot 24 \cdot 30(29 / 31)
$$

where $R_{\mathrm{A}}$ is the annual carbon flux of RS and its components $\left(\mathrm{g} \mathrm{C} \mathrm{m}^{-2} \mathrm{ha}^{-1} \mathrm{y}^{-1}\right) ; R_{\mathrm{i}}$ is the mean monthly respiration rates of RS and its components $\left(\mu \mathrm{mol} \mathrm{m} \mathrm{m}^{-2} \mathrm{~s}^{-1}\right) ; 10^{-6}$ is the unit conversion from $1 \mu \mathrm{mol}$ to $1 \mathrm{~mol} ; 12 / 44$ is the conversion from $\mathrm{CO}_{2}$ to $\mathrm{C} ; 1$ day $=3600$ $\times 24 \mathrm{~s} ; 30 \cdot(29 / 31)$ are the days of each month.

The net ecosystem production was calculated using the following equation (Luo \& Zhou 2006 - eqn. 7):

$$
N E P=N P P+R R_{A}-R S_{A}
$$

where NPP is the net primary production $(\mathrm{t}$ $\left.\mathrm{C} \mathrm{m}{ }^{-2} \mathrm{ha}^{-1} \mathrm{y}^{-1}\right)$, which was obtained as the annual increase in total woody biomass plus annual litterfall and vegetation, $R R_{\mathrm{A}}$ and $R S_{\mathrm{A}}$ are the annual carbon flux ( $\left.\mathrm{t} \mathrm{C} \mathrm{m} \mathrm{ma}^{-2} \mathrm{y}^{-1}\right)$ of $R R$ and $R S$, respectively.

\section{Results}

Seasonal variability in soil temperature and soil moisture

Fig. 1 showed the seasonal changes in soil moisture, soil temperature of IS, LS and TS. Soil temperature showed significant seasonal

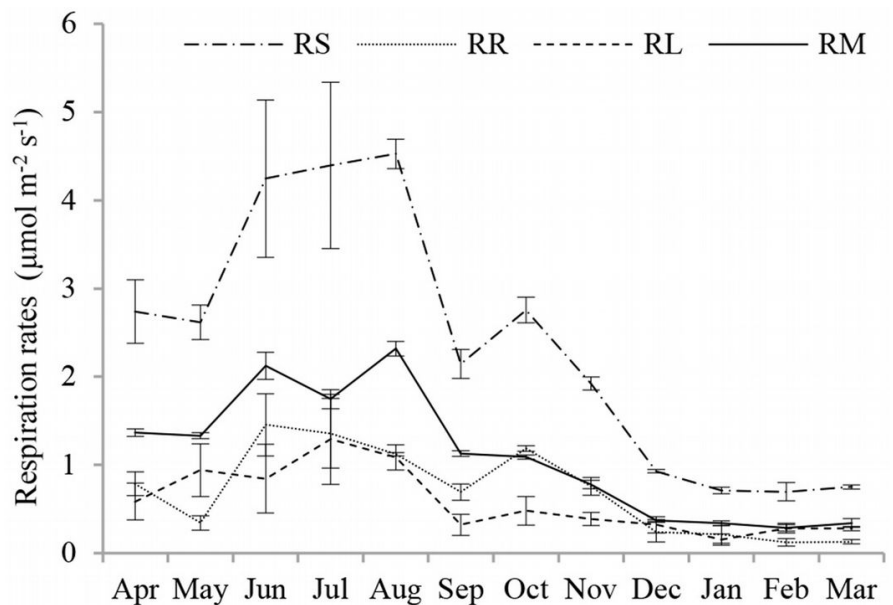

Fig. 2 - Seasonal variation in contributions of RR, RL and $\mathrm{RM}$ to RS in the Moso bamboo forest in Chibi city from April 2011 to March 2012. RS, RR, RL and RM represent total soil respiration, root respiration, litter respiration and soil organic matter derived respiration, respectively. Error bars represent the standard error $(\mathrm{n}=3)$. 
Fig. 3 - Seasonal dynamics of the contributions of RR,

RL and RM to RS in the

Moso bamboo forest in Chibi city from April 2011 to March 2012. RS, RR, RL and $\mathrm{RM}$ represent total soil respiration, root respiration, litter respiration and soil organic matter derived respiration, respectively. Error bars represent the standard error $(n=3)$.

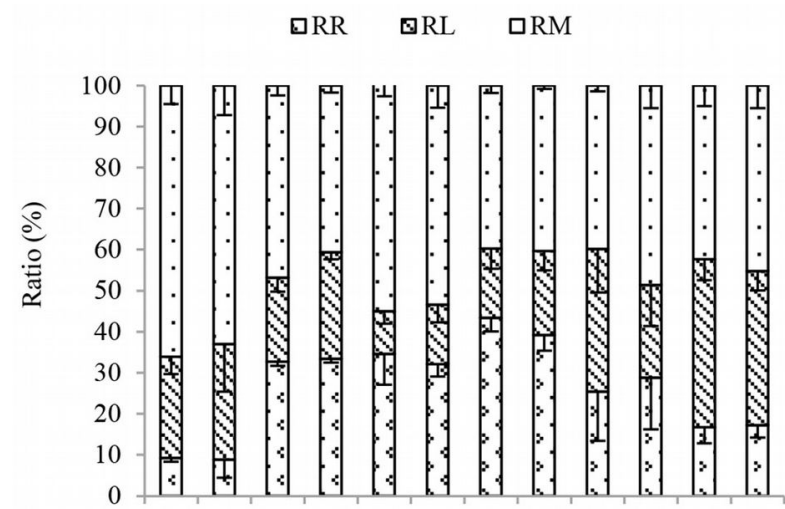

Apr May Jun Jul Aug Sep Oct Nov Dec Jan Feb Mar variability $(\mathrm{P}<0.001)$ ranging from $5.0^{\circ} \mathrm{C}$ in February in TS to $32.9^{\circ} \mathrm{C}$ in August in LS. Mean annual soil temperature was 19.7 ${ }^{\circ} \mathrm{C}, 19.5{ }^{\circ} \mathrm{C}$ and $19.6{ }^{\circ} \mathrm{C}$ for IS, LS and TS, respectively, with no significant differences among groups $(\mathrm{P}>0.05)$. Similarly, soil moisture ranged from $5.5 \%$ in December in IS to $35.3 \%$ in July in TS with significant seasonal variability $(\mathrm{P}<0.001)$. Soil moisture decreased in May due to a short drought period, and then increased significantly, starting to decrease again after August. How-

Tab. 2 - Fitted parameters of: (a) the exponential relationship between soil respiration ( $\mu$ mol $\left.\mathrm{m}^{-2} \mathrm{~s}^{-1}\right)$ and soil temperature $\left({ }^{\circ} \mathrm{C}-R S=a e^{\mathrm{bT}}\right)$; (b) the linear relationship between soil respiration and soil moisture $(\%-R S=a W+b)$; (c) bivariate models of soil temperature and moisture $(R S=a W T+b)$ for different source components. RS, RR, RL and RM represent total soil respiration, root respiration, litter respiration and soil organic matter derived respiration, respectively.

\begin{tabular}{llcccccc}
\hline Group & Components & $\boldsymbol{a}$ & $\boldsymbol{b}$ & $\mathbf{R}^{\mathbf{2}}$ & $\mathbf{n}$ & Prob & $\boldsymbol{Q}_{\mathbf{1 0}}$ \\
\hline (a) & RS & 0.555 & 0.062 & 0.862 & 36 & $<0.001$ & - \\
& RR & 0.099 & 0.076 & 0.510 & 36 & $<0.001$ & - \\
& RL & 0.161 & 0.050 & 0.456 & 36 & $<0.001$ & - \\
& RM & 0.224 & 0.069 & 0.925 & 36 & $<0.001$ & - \\
\hline (b) & RS & 0.127 & 0.140 & 0.778 & 36 & $<0.001$ & - \\
& RR & 0.036 & 0.047 & 0.553 & 36 & $<0.001$ & - \\
& RL & 0.029 & 0.060 & 0.410 & 36 & $<0.001$ & - \\
& RM & 0.059 & -0.026 & 0.890 & 36 & $<0.001$ & - \\
\hline (c) & RS & $3.452 \times 10^{-3}$ & 0.847 & 0.915 & 36 & $<0.001$ & 1.25 \\
& RR & $1.124 \times 10^{-3}$ & 0.193 & 0.588 & 36 & $<0.001$ & 1.15 \\
& RL & $0.585 \times 10^{-3}$ & 0.249 & 0.446 & 36 & $<0.001$ & 1.19 \\
& RM & $1.587 \times 10^{-3}$ & 0.406 & 0.869 & 36 & $<0.001$ & 1.26 \\
\hline
\end{tabular}
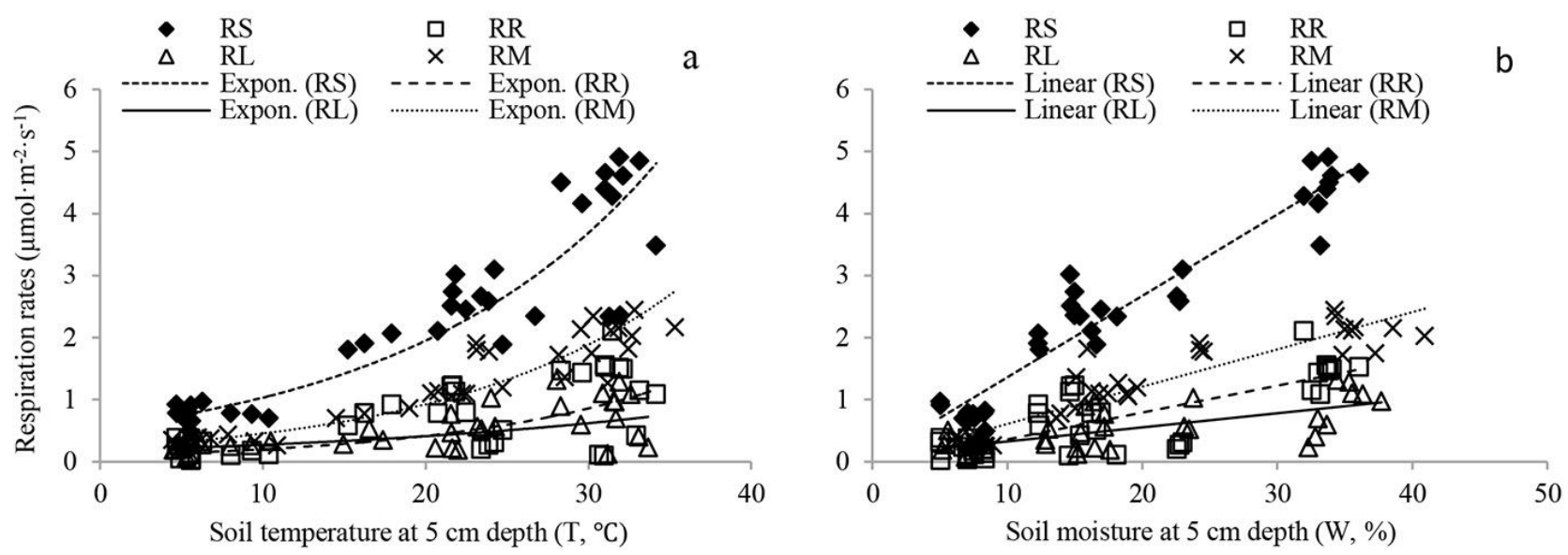

Fig. 4 - Relationship between RS and its source components and: (a) soil temperature at $5 \mathrm{~cm}$ depth (T, ${ }^{\circ} \mathrm{C}$ ); (b) soil moisture (W, \%) at depth of $5 \mathrm{~cm}$ in the Moso bamboo forest in Chibi city from April 2011 to March 2012. RS, RR, RL and RM represent total soil respiration, root respiration, litter respiration and soil organic matter derived respiration, respectively. Fitting parameters are reported in Tab. 2. 
Fig. 5 - Seasonal variability of carbon input by litter (t C $\left.\mathrm{ha}^{-1}\right)$ at the Moso bamboo forest in Chibi city from April 2011 to March 2012.

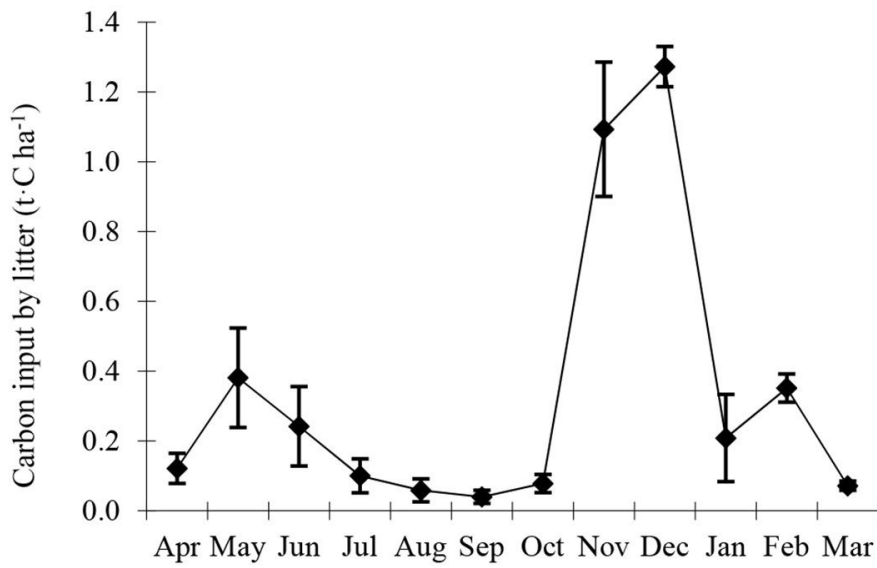

of the total variation in RS and its source components. Positive linear correlations were found between respiration rates and soil moisture (Fig. 4b, Tab. 2). Soil moisture accounted for $41-89 \%$ of the total variation in RS and its source components.

Two-factor models were applied to analyze the co-effect of soil temperature and moisture on RS. The interaction of soil temperature and moisture explained $45-92 \%$ of the total variation in RS and its source components (Tab. 2). Temperature sensitivity $\left(Q_{10}\right)$ values of RS, RR, RL and RM (calculated from monthly changes in respiration rates and temperature) were $1.25,1.15,1.19$ and 1.26 , respectively. The $Q_{10}$ value of RM was the highest, while the $Q_{10}$ value of RR was the lowest.

\section{Carbon balance}

Significant seasonal variability $(\mathrm{P}<0.001)$ was observed in carbon input by litter (Fig. 5). Carbon input by litter was lowest in September $\left(0.04 \mathrm{t} \mathrm{C} \mathrm{ha}^{-1}\right)$ and peaked in December $\left(1.27 \mathrm{t} \mathrm{C} \mathrm{ha}^{-1}\right)$, with a monthly average of $0.33 \mathrm{t} \mathrm{C} \mathrm{ha}^{-1}$. Annual RM was the highes among source components with $4.41 \mathrm{t} \mathrm{C} \mathrm{ha}^{-1}$ $\mathrm{y}^{-1}$ while annual RL was the lowest with 1.95 t C ha ${ }^{-1} \mathrm{y}^{-1}$. More than $95 \%$ of carbon input

Tab. 3 - Various components of ecosystem carbon flux in the Moso bamboo forest in Chibi city from April 2011 to March 2012 (t $\mathrm{C} \mathrm{ha}^{-1} \mathrm{y}^{-1}$ ). RS, RR, RL and RM represent total soil respiration, root respiration, litter respiration and soil organic matter derived respiration, respectively.

\begin{tabular}{ll}
\hline Parameter & Value \\
\hline RS & $8.97 \pm 0.17$ \\
RR & $2.61 \pm 0.10$ \\
RL & $1.95 \pm 0.09$ \\
RM & $4.41 \pm 0.05$ \\
Age 1 (du) & $6.26 \pm 0.11$ \\
Age 2 & $0.07 \pm 0.03$ \\
Age $\geq 3$ & $0.04 \pm 0.01$ \\
Litter & $4.02 \pm 0.20$ \\
Understory & $0.69 \pm 0.07$ \\
NEP & 4.72 \\
\hline
\end{tabular}

by bamboo was from $1 \mathrm{du}$ bamboos, and this changed little as age increased (Tab. 3). Annual carbon input from litter and vegetation were 4.02 and $0.69 \mathrm{t} \mathrm{C} \mathrm{ha}^{-1} \mathrm{y}^{-1}$, respectively. NEP was $4.72 \mathrm{t} \mathrm{C} \mathrm{ha}^{-1} \mathrm{y}^{-1}$, indicating that the Moso bamboo forest acted as a carbon sink.

\section{Discussion}

\section{Annual variability of $R S$}

RS showed a noticeable seasonality, and had an annual average rate of $2.37 \mu \mathrm{mol} \mathrm{m}^{-2}$ $\mathrm{s}^{-1}$, which was within the range reported for Chinese forest ecosystems $(0.62-7.98 \mu \mathrm{mol}$ $\mathrm{m}^{-2} \mathrm{~s}^{-1}$ - Chen et al. 2008). However, the rate observed in this study was higher than that reported for evergreen broadleaved forests $\left(1.63 \mu \mathrm{mol} \mathrm{m} \mathrm{m}^{-2} \mathrm{~s}^{-1}\right)$, mixed evergreen and deciduous broadleaved forests $\left(1.79 \mu \mathrm{mol} \mathrm{m} \mathrm{m}^{-2}\right.$ $\left.\mathrm{s}^{-1}\right)$, deciduous broadleaved forests $(1.74$ $\left.\mu \mathrm{mol} \mathrm{m} \mathrm{m}^{-2} \mathrm{~s}^{-1}\right)$ and sub-alpine coniferous forests $\left(1.35 \mu \mathrm{mol} \mathrm{m} \mathrm{m}^{-2} \mathrm{~s}^{-1}\right)$ of the Shennongia Forest Region, which is $500 \mathrm{~km}$ away from our study area in the same climate zone (Luo et al. 2011). On the other hand, the observed annual RS rate was lower than that reported for the Moso bamboo forest of the Tianmu Mountain, Zhejiang province $\left(3.82 \mu \mathrm{mol} \mathrm{m}{ }^{-2}\right.$ $\mathrm{s}^{-1}$ - Song et al. 2013), and for the Wangmuling natural reserve in the Fujian province

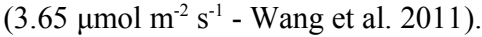

The factors contributing to the variability of RS among different forest ecosystems were complex. Likely, a major reason is the carbon availability from photosynthesis to RS (Ryan \& Law 2005). Vegetation structure and species composition may strongly influence carbon allocation patterns (Wang et al. 2001). Increases of carbon transfer from aboveground to belowground due to a longer photosynthesis period in evergreen pine plantations increase root biomass and RS as compared with deciduous larch plantations, but have no influence on heterotrophic respiration (Wang \& Yang 2007). It has been proved that higher NPP in the Moso bamboo forest caused 1.89 times higher RS than that of Chinese fir stands in the same study area (Xiao 2007). A second potential reason may be the belowground dynamics, since RS is strongly related with root biomass and root nitrogen concentration (Burton et al. 2002, Wang et al. 2006). Soil organic carbon (SOC) concentration, especially the newly labile SOC produced by litter, may be a third potential factors affecting the RS variability. The Moso bamboo forest produced less readily decomposable litter than Chinese fir stands (Xiao 2007), and broadleaved forest (Landsberg \& Gower 1997). A fourth reason might be attributable to differences in temperature, which becomes a major control of RS at regional level (Raich \& Schlesinger 1992, Wang et al. 2010). The temperature dependence of RS varies across forest ecosystems, though RS is controlled by soil temperature at a regional scale, as demonstrated by many studies (Fan et al. 2009, Rey et al. 2002, Tu et al. 2013, Wang et al. 2011). Indeed, the Moso bamboo forest in the Hu'nan province with lower annual temperature showed lower RS rates as compared with this study $\left(16.5 v s .19 .6{ }^{\circ} \mathrm{C}\right.$ - Fan et al. 2009), while the Moso bamboo forest in the Fujian province had higher RS rate (19.6 vs. $22.5^{\circ} \mathrm{C}$ - Wang et al. 2011).

\section{Contribution of source components to $R S$}

In this study, a large range in the contribution of RR to RS has been reported (10-90\% - Hanson et al. 2000). Such variability may partly result from methodological issues and partly from differences in forest types and soil conditions (Hanson et al. 2000). Annual contribution of RR to total RS was $29 \%$, which is similar to that reported for temperate mixed hardwood forests $(33 \%$ - Bowden et al. 1993) and to the average contribution of main forest types in China (34.7\% - Chen et al. 2008). However, it was relatively low when compared with other forests types $(\mathrm{Li}$ et al. 2006, Ohashi et al. 2000, Tu et al. $2013)$ and with the world average (46\% Hanson et al. 2000).

$\mathrm{Li}$ et al. (2006) ascribed the low contribution of RR to RS to different forest types, stand ages and forest structures, while Rey et al. (2002) attributed it to the decrease of NEE and NPP due to coppicing, logging operation (decrease in LAI), and the increase in litter and detritus both above- and belowground. The low contribution of RR to RS could be also partly due to the trenching treatment. An increase in dead root mass due to trenching may have increased the root debris, whose decomposition rate may differ depending on forest type, ranging from several months to one year (Rey et al. 2002, Yang et al. 2007). To minimize such trenching effect, it has been suggested to measure the RS several months later, when the respiration rate in the trenched plots is stable (Hanson et al. 2000, Yang et al. 2007). However, the decomposition of dead roots has 
been asserted to occur in the first month (Kelting et al. 1998) and Bowden et al. (1993) further argued that the influence of dead root decomposition could be ignored, though they did not measure long-term decomposition of dead roots. To evaluate the early responses of $\mathrm{RS}$ to trenching in this study, RS was measured one month later. This could lead to an underestimation of the $\mathrm{RR}$, and to an overestimation of the RM. Thus, the annual RM contribution to RS was as high as $49 \%$, especially in the first few months. Additionally, higher water availability in TS compared with IS and LS (Fig. 1b) could increase the contribution of RM to RS, because RM was strongly positively related with soil moisture. The annual contribution of RL to RS was $22 \%$, which was similar to other studies (Bowden et al. 1993, Rey et al. 2002, Tu et al. 2013).

\section{Effects of soil temperature on $R S$}

RS and soil temperature are often exponentially related in forests (Rey et al. 2002, Tu et al. 2013, Wang et al. 2006). Such kind of relationship was also found in the Moso bamboo forest analyzed in this study. Soil temperature accounted for most of the variation in RS and its source components, indicating that soil temperature is one of the most important drivers of RS variability.

To describe the dependence of RS on temperature, the $Q_{10}$ value was applied. The $Q_{10}$ value is always calculated from a time series of measured RS values, and well depicts the response of RS to changes in temperature (Rey et al. 2002). $Q_{10}$ values in this study varied from 1.15 to 1.26 , which are close to the range (1.28-5.53) reported for the main forest types in China (Chen et al. 2008, Zheng et al. 2009). Also, the values observed in this study are lower than those reported for aspen-birch forests (3.75), a temperate mixed hardwood forest in Harvard Forest (3.9), evergreen broadleaved forests (2.38), mixed evergreen and deciduous broadleaved forests (2.68), deciduous broadleaved forest (2.99) and sub-alpine coniferous forest (4.24) in the Shennongjia Forest Region (Davidson et al. 1998, Luo et al. 2011, Wang et al. 2006). The $Q_{10}$ of the different source components was different, suggesting that different RS components had different responses to soil temperature. $Q_{1}$ value of $R R$ was the lowest, indicating that $\mathrm{RR}$ is less sensitive to soil temperature than other components of RS. This is inconsistent with data from mixed temperate forests (Boone et al. 1998), likely because bamboo forests show high activities in winter and early spring, due to the growth of shoots.

The large variability of $Q_{10}$ values across different ecosystems may be partly attributed to the different methodology applied and partly to environmental factors. First, soil temperature at different depths can result in different $Q_{10}$ values. Khomik et al. (2006) measured the mean soil temperature in a boreal mixed wood forest at 2, 5, 10, 15, 20 and $50 \mathrm{~cm}$ depths, and found $Q_{10}$ values in the range 3.6 to 12.7 , though the highest coefficients of RS to soil temperature were found at $10 \mathrm{~cm}$ depth. Borken et al. (2002) reported similar values of $Q_{10}$ for European beech, Norway spruce and Scots pine forests, ranging from 1.87 at $0 \mathrm{~cm}$ to 3.46 at 10 $\mathrm{cm}$ of depth. Based on the above evidence, such authors suggested to model the relationship between RS and soil temperature using data measured at $5-10 \mathrm{~cm}$, which is the depth where the highest proportion of $\mathrm{CO}_{2}$ along the profile is released. Second, $Q_{10}$ values may change depending on the timescale considered. Based on the same dataset, Janssens \& Pilegaard (2003) obtained seasonal and annual $Q_{10}$ values ranging from 1.3 to 5.5 , with an annual average of 4.2 in a beech forest. Long-term continuous datasets are required to throw light on the temperature dependence of $Q_{10}$ value of RS. The third reason underlying the large variability of $Q_{10}$ is the calculation method. In most studies, the calculation of $Q_{10}$ was based on an exponential model $\left(Q_{10}=e^{\mathrm{bT}}-\right.$ Borken et al. 2002, Fan et al. 2009, Wang \& Yang 2007). However, because of the strong co-variation with soil moisture, one-factor regression models are not well suited for analyzing the relationship between RS and soil temperature. In this study, a two-factor model was applied to calculate $Q_{10}$ (eqn. 5). Our results showed that one-factor models tend to overestimate $Q_{10}$ (data not shown), likely because of water stress in winter and early spring. Although widely adopted in different studies of soil temperature, the use of $Q_{10}$ as the only variable is somehow limiting (Davidson et al. 2006a). For example, the assumption of constant temperature sensitivities of respiratory enzymes does not hold at all temperatures (Atkin \& Tjoelker 2003). Rapid changes in substrate availability (Högberg et al. 2001), clipping and shading (Wan \& Luo 2003), kinetics of SOM decomposition (Davidson \& Janssens 2006), and the occurrence of drying and rewetting cycles (Shi \& Marschner 2014) also clearly affect soil respiration independent of temperature. Therefore, the annual $Q_{10}$ value did not only reflect the dependence of RS on soil temperature, but also includes the effects of changes of plant phonological patterns, substrate availability, soil temperature and moisture (Janssens \& Pilegaard 2003).

\section{Effects of soil moisture on RS}

Soil moisture is another important factor affecting RS. In this study, RS and its source components were linearly related with soil moisture at $5 \mathrm{~cm}$ depth, similar to previous studies (Li et al. 2006, 2008). Very high or low soil moisture constrained RS by limiting aeration (Davidson et al. 1998, Xu \& Qi 2001). For example, the lowest RS rate was observed in summer in a Mediterranean mixed oak forest due to summer drought (Rey et al. 2002). In the current study, a similar occurrence was observed in May, when RS and its source components decreased despite the increase of soil temperature, as a consequence of a short drought period that led to a decrease in the soil moisture (Fig. 1b and Fig. 2).

\section{Combined effects of soil temperature and moisture on $R S$}

RS is often modeled as a function of either soil temperature or soil moisture $(\mathrm{Xu} \& \mathrm{Qi}$ 2001). However, temperature and moisture co-vary in the soil, making difficult to distinguish their individual effects on RS. Soil moisture limits RS in dry areas or during dry seasons (Rey et al. 2002) and soil temperature controls RS in low temperature areas or seasons, especially at high altitudes (BondLamberty \& Thomson 2010, Li et al. 2008).

In this study, two-factor equations were applied to model the combined effects of soil temperature and moisture on RS. These models explained $45-92 \%$ of the variation in RS, which was consistent with previous studies (Davidson et al. 1998, Xu \& Qi 2001). Compared with a one-factor model, the twofactor models were able to describe the seasonal variability and co-effect of soil temperature and soil moisture on RS, especially when either one or the other are the limiting factors (Davidson et al. 1998, Kang et al. 2003, Xu \& Qi 2001). However, the $\mathrm{R}^{2}$ of the two-factor model was relatively low for $\mathrm{RR}$ and RL, as compared with that obtained for RS and RM, indicating that other factors may be responsible for the variability of RR and RL, such as carbohydrates, root biomass, root activity, soil nutrient availability and litter biomass (Lee \& Jose 2003, Pregitzer et al. 2000, Ryan et al. 1996, Yan et al. 2006). This fact has been underrated in most RS studies, because temperature variability is highly correlated with solar radiation, masking the direct effect of photosynthesis on substrate availability in the soil (Kuzyakov \& Gavrichkova 2010).

\section{Carbon balance}

RS studies carried out in Moso bamboo forests are very scarce in the literature. Fan et al. (2009) reported an annual $\mathrm{CO}_{2}$ flux estimate of $33.94 \mathrm{t} \mathrm{CO}_{2} \mathrm{ha}^{-1} \mathrm{y}^{-1}$ (equaling $9.26 \mathrm{t}$ $\left.\mathrm{C} \mathrm{ha}^{-1} \mathrm{y}^{-1}\right)$ in a Moso bamboo forest located in the Huitong county, Hunan province (subtropical China), which was comparable to that obtained in this study $\left(8.97 \mathrm{t} \mathrm{Cha}^{-1} \mathrm{y}^{-1}\right)$. On the other hand, our estimate was lower than that reported for both intensively managed and conventional Moso bamboo forests (15.98 and $10.88 \mathrm{t} \mathrm{C} \mathrm{ha}^{-1} \mathrm{y}^{-1}$, respectively) in Lin'an, Zhejiang province, which has higher 
precipitation (1629 mm - Liu et al. 2011).

In contrast to bamboo forests, several studies have examined RS in other forest types of subtropical China. Xiao et al. (2010) reported an annual $\mathrm{CO}_{2}$ flux in a Chinese fir plantation of $19.88 \mathrm{t} \mathrm{CO}_{2} \mathrm{ha}^{-1} \mathrm{y}^{-1}$ (equaling $\left.5.42 \mathrm{t} \mathrm{C} \mathrm{ha}^{-1} \mathrm{y}^{-1}\right)$ in Huitong county, Hunan province. Yang et al. (2007) measured RS in Castanopsis kawakamii and adjacent monoculture evergreen plantations of C. kawakamii and Cunninghamia lanceolata in the subtropical Sanming Nature Reserve, Fujian Province, estimating an annual RS of 13.74 9.44 and $4.54 \mathrm{t} \mathrm{C} \mathrm{ha}^{-1} \mathrm{y}^{-1}$, respectively. Such large variation in estimates suggests that forest types and climate conditions had significant effects on annual RS. Therefore, the availability of data on RS in different forest types and climate zones is critical to accurately predict global carbon cycles and its responses to climate change.

NEP of terrestrial ecosystems is a key process for actively managing the carbon cycle (Harmon et al. 2004). In this study, NEP estimate was $4.72 \mathrm{t} \mathrm{C} \mathrm{ha-}^{-1} \mathrm{y}^{-1}$, indicating that the investigated Moso bamboo forest acts as carbon sink. However, such estimate was higher than that obtained for a similar forest in the Hunan province $\left(3.96 \mathrm{t} \mathrm{C}^{\mathrm{C}} \mathrm{ha}^{-1} \mathrm{y}^{-1}\right.$ Xiao et al. 2010), as well as for an open eucalypt savanna in northern Australia (3.8 t C $\mathrm{ha}^{-1} \mathrm{y}^{-1}$ - Chen et al. 2003). Contrastingly, annual NEP estimated in this study was lower than that reported for a European temperate deciduous forest (5.9 $\mathrm{t} \mathrm{C} \mathrm{ha}^{-1} \mathrm{y}^{-1}$ - Malhi et al. 1999) and a natural evergreen forest of Cas tanopsis kawakamii $\left(7.5 \mathrm{t} \mathrm{C} \mathrm{ha}^{-1} \mathrm{y}^{-1}\right)$, but close to that from a Castanopsis kawakamii plantation in China $\left(4.1 \mathrm{t} \mathrm{C} \mathrm{ha}^{-1} \mathrm{a}^{-1}\right.$ - Yang et al. 2007). Xiao et al. (2010) attributed such large differences in NEP estimates not only to tree species and their biological characteristics, but also to site conditions. Malhi et al. (1999) concluded that the use of different methods (e.g., eddy flux measurement, estimation derived from component processes) also caused a great bias in annual NEP estimation.

\section{Conclusion}

This study provides a better understanding of the RS and carbon balance of Moso bamboo forests in subtropical China, and contributes to estimate a global carbon balance across different forest types. RS and its source components varied across seasons, mainly in response to soil temperature and moisture changes and their interactions. Two-factor models using both soil temperature and moisture as predictors accounted for variation in RS and its components better than either soil temperature or moisture. RM contributed half to RS, while RL contributed only $22 \%$. NEP estimate was $4.72 \mathrm{t} \mathrm{C} \mathrm{ha}^{-1} \mathrm{y}^{-1}$, indicating that the Moso bamboo forest investigated acts as carbon sink.

\section{Acknowledgements}

The study was supported by Special Funds for Forestry Public Industry Research (201104008); Special funds for basic research of International centre for Bamboo and Rattan (1632013010); key special funds of Jiangxi province (2011511101). The authors thank Qingbiao Xu for carrying the fieldwork and lab work, and Jin Yu, Chuxin Shen for fieldwork support.

\section{References}

Atkin OK, Tjoelker MG (2003). Thermal acclimation and the dynamic response of plant respiration to temperature. Trends in plant science 8 (7): 343-351. - doi: 10.1016/S1360-1385(03)00 $136-5$

Bond-Lamberty B, Thomson A (2010). Temperature-associated increases in the global soil respiration record. Nature 464 (7288): 579-582. - doi: 10.1038/nature08930

Bond-Lamberty B, Wang C, Gower ST (2004). A global relationship between the heterotrophic and autotrophic components of soil respiration? Global Change Biology 10 (10): 1756-1766. doi: 10.1111/j.1365-2486.2004.00816.x

Boone RD, Nadelhoffer KJ, Canary JD, Kaye JP (1998). Roots exert a strong influence on the temperature sensitivity of soil respiration. Nature 396 (6711): 570-572. - doi: 10.1038/25119

Borken W, Xu Y-J, Davidson EA, Beese F (2002). Site and temporal variation of soil respiration in European beech, Norway spruce, and Scots pine forests. Global Change Biology 8 (12): 12051216. - doi: 10.1046/j.1365-2486.2002.00547.x Bowden RD, Nadelhoffer KJ, Boone RD, Melillo JM, Garrison JB (1993). Contributions of aboveground litter, belowground litter, and root respiration to total soil respiration in a temperate mixed hardwood forest. Canadian Journal of Forest Research 23 (7): 1402-1407. - doi: 10.1139/x93177

Burton A, Pregitzer K, Ruess R, Hendrick R, Allen M (2002). Root respiration in North American forests: effects of nitrogen concentration and temperature across biomes. Oecologia 131 (4): 559-568. - doi: 10.1007/s00442-002-0931-7 Chen X, Hutley LB, Eamus D (2003). Carbon balance of a tropical savanna of northern Australia. Oecologia 137 (3): 405-416. - doi: 10.1007/s004 42-003-1358-5

Chen G, Yang Y, Lu P, Zhang Y, Qian X (2008). Regional patterns of soil respiration in China's forests. Acta Ecologica Sinica 28 (4): 17481761

Chen XG, Zhang XQ, Zhang YP, Booth T, He XH (2009). Changes of carbon stocks in bamboo stands in China during 100 years. Forest Ecology and Management 258 (7): 1489-1496. - doi: 10.1016/j.foreco.2009.06.051

China Green Foundation (2008). Carbon sink afforestation projects metering and monitoring guidelines. Chinese Forestry Publisher, Beijing, China, pp. 59.

Davidson EA, Belk E, Boone RD (1998). Soil water content and temperature as independent or confounded factors controlling soil respiration in a temperate mixed hardwood forest. Global Change Biology 4 (2): 217-227. - doi: 10.1046/ j.1365-2486.1998.00128.x

Davidson EA, Verchot LV, Catt'nio JH, Ackerman IL, Carvalho JEM (2000). Effects of soil water content on soil respiration in forests and cattle pastures of eastern Amazonia. Biogeochemistry 48 (1): 53-69. - doi: 10.1023/a:10062 04113917

Davidson EA, Janssens IA (2006). Temperature sensitivity of soil carbon decomposition and feedbacks to climate change. Nature 440 (7081): 165-173. - doi: 10.1038/nature04514

Davidson EA, Janssens IA, Luo Y (2006a). On the variability of respiration in terrestrial ecosystems: moving beyond Q10. Global Change Biology 12 (2): 154-164. - doi: 10.1111/j.13652486.2005.01065.x

Davidson EA, Richardson AD, Savage KE, Hollinger DY (2006b). A distinct seasonal pattern of the ratio of soil respiration to total ecosystem respiration in a spruce-dominated forest. Global Change Biology 12 (2): 230-239. - doi: 10.1111/ j.1365-2486.2005.01062.x

Edwards NT, Sollins P (1973). Continuous measurement of carbon dioxide evolution from partitioned forest floor components. Ecology 54 (2): 406-412. - doi: 10.2307/1934349

Epron D, Nouvellon Y, Roupsard O, Mouvondy W, Mabiala A, Saint-André L, Joffre R, Jourdan C, Bonnefond JM, Berbigier P, Hamel O (2004). Spatial and temporal variations of soil respiration in a Eucalyptus plantation in Congo. Forest Ecology and Management 202 (1-3): 149-160. doi: 10.1016/j.foreco.2004.07.019

Fan S, Xiao F, Wang S, Guan F, Yu X, Shen Z (2009). Soil respiration of moso bamboo plantation in Huitong, Hu'nan Province. Acta Ecologica Sinaca 29 (11): 5971-5977. [in Chinese with English abstract]

Gomez-Casanovas N, Matamala R, Cook DR, Gonzalez-Meler MA (2012). Net ecosystem exchange modifies the relationship between the autotrophic and heterotrophic components of soil respiration with abiotic factors in prairie grasslands. Global Change Biology 18 (8): 25322545. - doi: 10.1111/j.1365-2486.2012.02721.x Hanson PJ, Edwards NT, Garten CT, Andrews JA (2000). Separating root and soil microbial contributions to soil respiration: a review of methods and observations. Biogeochemistry 48 (1): 115146. - doi: 10.1023/a:1006244819642

Harmon M, Bible K, Ryan M, Shaw D, Chen H, Klopatek J, Li X (2004). Production, respiration, and overall carbon balance in an old-growth Pseudotsuga-Tsuga forest ecosystem. Ecosystems 7 (5): 498-512. - doi: 10.1007/s10021-0040140-9

Högberg MN, Högberg P (2002). Extramatrical ectomycorrhizal mycelium contributes one-third of microbial biomass and produces, together with associated roots, half the dissolved organic carbon in a forest soil. New Phytologist 154 (3): 791-795. - doi: 10.1046/j.1469-8137.2002.0041 7.x 
Högberg P, Nordgren A, Buchmann N, Taylor AFS, Ekblad A, Hogberg MN, Nyberg G, Ottosson-Lofvenius M, Read DJ (2001). Large-scale forest girdling shows that current photosynthesis drives soil respiration. Nature 411 (6839): 789792. - doi: $10.1038 / 35081058$

IPCC (2007). Climate change 2007: synthesis report. Contribution of Working Groups I, II and III to the Fourth Assessment Report of the Intergovernmental Panel on Climate Change. Oslo, Norway, pp. 36-41.

Janssens IA, Pilegaard KIM (2003). Large seasonal changes in $\mathrm{Q}_{10}$ of soil respiration in a beech forest. Global Change Biology 9 (6): 911 918. - doi: 10.1046/j.1365-2486.2003.00636.x

Janssens IA, Lankreijer H, Matteucci G, Kowalski AS, Buchmann N, Epron D, Pilegaard K, Kutsch W, Longdoz B, Grünwald T, Montagnani L, Dore S, Rebmann C, Moors EJ, Grelle A, Rannik Morgenstern K, Oltchev S, Clement R, Gu J, Minerbi S, Berbigier P, Ibrom A, Moncrieff J, Aubinet M, Bernhofer C, Jensen NO, Vesala T, Granier A, Schulze ED, Lindroth A, Dolman AJ, Jarvis PG, Ceulemans R, Valentini R (2001). Productivity overshadows temperature in determining soil and ecosystem respiration across $\mathrm{Eu}-$ ropean forests. Global Change Biology 7 (3): 269-278. - doi: 10.1046/j.1365-2486.2001.0041 2.x

Jia Z, Zhang J, Wang X, Xu J, Li Z (2009). Report for Chinese forest resource - The $7^{\text {th }}$ national forest inventory. China Forestry Publishing House, Beijing, China, pp. 2. [in Chinese]

Kang S, Doh S, Lee D, Lee D, Jin VL, Kimball JS (2003). Topographic and climatic controls on soil respiration in six temperate mixed-hardwood forest slopes, Korea. Global Change Biology 9 (10): 1427-1437. - doi: 10.1046/j.1365-2486.20 03.00668.x

Kelting DL, Burger JA, Edwards GS (1998). Estimating root respiration, microbial respiration in the rhizosphere, and root-free soil respiration in forest soils. Soil Biology and Biochemistry 30 (7): 961-968. - doi: 10.1016/S0038-0717(97)00 186-7

Khomik M, Arain MA, McCaughey JH (2006). Temporal and spatial variability of soil respiration in a boreal mixedwood forest. Agricultural and Forest Meteorology 140 (1-4): 244-256. doi: 10.1016/j.agrformet.2006.08.006

King JS, Hanson PJ, Bernhardt E, De Angelis P, Norby RJ, Pregitzer KS (2004). A multiyear synthesis of soil respiration responses to elevated atmospheric $\mathrm{CO}_{2}$ from four forest FACE experiments. Global Change Biology 10 (6): 10271042. - doi: 10.1111/j.1529-8817.2003.00789.x

Kuzyakov Y, Gavrichkova O (2010). Time lag between photosynthesis and carbon dioxide efflux from soil: a review of mechanisms and controls. Global Change Biology 16 (12): 3386-3406. doi: 10.1111/j.1365-2486.2010.02179.x

Kuzyakov Y (2006). Sources of $\mathrm{CO}_{2}$ efflux from soil and review of partitioning methods. Soil Biology and Biochemistry 38 (3): 425-448. - doi: 10.1016/j.soilbio.2005.08.020

Landsberg JJ, Gower ST (1997). Applications of physiological ecology to forest management. Academic Press, San Diego, CA, USA, pp. 602. Law BE, Falge E, Gu L, Baldocchi DD, Bakwin P, Berbigier P, Davis K, Dolman AJ, Falk M, Fuentes JD, Goldstein A, Granier A, Grelle A, Hollinger D, Janssens IA, Jarvis P, Jensen NO, Katul G, Mahli Y, Matteucci G, Meyers T, Monson R, Munger W, Oechel W, Olson R, Pilegaard K, Paw KT U, Thorgeirsson H, Valentini R, Verma S, Vesala T, Wilson K, Wofsy S (2002). Environmental controls over carbon dioxide and water vapor exchange of terrestrial vegetation. Agricultural and Forest Meteorology 113 (1-4): 97-120. - doi: 10.1016/S0168-1923(02)00104-1 Lee K-H, Jose S (2003). Soil respiration, fine root production, and microbial biomass in cottonwood and loblolly pine plantations along a nitrogen fertilization gradient. Forest Ecology and Management 185 (3): 263-273. - doi: 10.1016/ S0378-1127(03)00164-6

Lee MS, Nakane K, Nakatsubo T, Koizumi H (2003). Seasonal changes in the contribution of root respiration to total soil respiration in a cooltemperate deciduous forest. Plant and Soil 255 (1): 311-318. - doi: 10.1023/A:1026192607512

Li YQ, Xu M, Zou XM (2006). Heterotrophic soil respiration in relation to environmental factors and microbial biomass in two wet tropical forests. Plant and Soil 281 (1-2): 193-201. - doi: 10.1007/s11104-005-4249-1

Li HJ, Yan JX, Yue XF, Wang MB (2008). Significance of soil temperature and moisture for soil respiration in a Chinese mountain area. Agricultural and Forest Meteorology 148 (3): 490-503. doi: 10.1016/j.agrformet.2007.10.009

Li Y, Jian H, Yuan F (2010). Soil respiration and its regulating factors in the Phyllostachys edulis forest of west Tianmu Mountain. Acta Ecologica Sinica 30 (17): 4590-4597. - doi: 10.1016/j.chn aes.2009.12.001

Liu J, Jiang PK, Wang HL, Zhou GM, Wu JS, Yang F, Qian XB (2011). Seasonal soil $\mathrm{CO}_{2}$ efflux dynamics after land use change from a natural forest to Moso bamboo plantations in subtropical China. Forest Ecology and Management 262 (6): 1131-1137. - doi: 10.1016/j.foreco.2011 .06 .015

Luo Y, Zhou X (2006). Soil respiration and the environment. Academic Press, San Diego, CA, USA, pp. 18-20.

Luo L, Shen GZ, Xie ZQ, Zhou LG (2011). Components of soil respiration and its temperature sensitivity in four types of forests along an elevational gradient in Shennongjia, China. Chinese Journal of Plant Ecology 35 (7): 722-730. [in Chinese] - doi: 10.3724/SP.J.1258.2011.00722

Malhi Y, Baldocchi DD, Jarvis PG (1999). The carbon balance of tropical, temperate and boreal forests. Plant, Cell and Environment 22 (6): 715740. - doi: 10.1046/j.1365-3040.1999.00453.x

Ohashi M, Gyokusen K, Saito A (2000). Contribution of root respiration to total soil respiration in a Japanese cedar (Cryptomeria japonica D. Don) artificial forest. Ecological Research 15 (3): 323-333. - doi: 10.1046/j.1440-1703.2000. 00351.x
Pang XY, Bao WK, Zhu B, Cheng WX (2013). Responses of soil respiration and its temperature sensitivity to thinning in a pine plantation. Agricultural and Forest Meteorology 171: 57-64. doi: 10.1016/j.agrformet.2012.12.001

Pregitzer KS, King JS, Burton AJ, Brown SE (2000). Responses of tree fine roots to temperature. New Phytologist 147 (1): 105-115. - doi: 10.1046/j.1469-8137.2000.00689.x

Raich JW, Schlesinger WH (1992). The global carbon dioxide flux in soil respiration and its relationship to vegetation and climate. Tellus B 44 (2): 81-99. - doi: 10.1034/j.1600-0889.1992.t011-00001.x

Raich JW, Potter CS, Bhagawati D (2002). Interannual variability in global soil respiration, 1980-94. Global Change Biology 8 (8): 800-812. - doi: 10.1046/j.1365-2486.2002.00511.x

Rey A, Pegoraro E, Tedeschi V, De Parri I, Jarvis PG, Valentini R (2002). Annual variation in soil respiration and its components in a coppice oak forest in Central Italy. Global Change Biology 8 (9): 851-866. - doi: 10.1046/j.1365-2486.2002. 00521.x

Ryan MG, Law BE (2005). Interpreting, measuring, and modeling soil respiration. Biogeochemistry 73 (1): 3-27. - doi: 10.1007/s10533-0045167-7

Ryan MG, Hubbard RM, Pongracic S, Raison RJ, McMurtrie RE (1996). Foliage, fine-root, woody-tissue and stand respiration in Pinus radiata in relation to nitrogen status. Tree Physiology 16 (3): 333-343. - doi: 10.1093/treephys/16.3.333 Saiz G, Byrne KA, Butterbach-Bahl K, Kiese R, Blujdea V, Farrell EP (2006). Stand age-related effects on soil respiration in a first rotation Sitka spruce chronosequence in central Ireland. Global Change Biology 12 (6): 1007-1020. - doi: 10.11 11/j.1365-2486.2006.01145.x

Shi AD, Marschner P (2014). Drying and rewetting frequency influences cumulative respiration and its distribution over time in two soils with contrasting management. Soil Biology and Biochemistry 72 (0): 172-179. - doi: 10.1016/j.soilbio.2014.02.001

Song X, Yuan H, Kimberley MO, Jiang H, Zhou $\mathrm{G}$, Wang $\mathrm{H}$ (2013). Soil $\mathrm{CO}_{2}$ flux dynamics in the two main plantation forest types in subtropical China. Science of The Total Environment 444:363-368. - doi: 10.1016/j.scitotenv.2012.12. 006

Subke J-A, Inglima I, Cotrufo MF (2006). Trends and methodological impacts in soil $\mathrm{CO}_{2}$ efflux partitioning: a meta-analytical review. Global Change Biology 12 (6): 921-943. - doi: 10.1111/ j.1365-2486.2006.01117.x

Suseela V, Conant RT, Wallenstein MD, Dukes JS (2012). Effects of soil moisture on the temperature sensitivity of heterotrophic respiration vary seasonally in an old-field climate change experiment. Global Change Biology 18 (1): 336348. - doi: 10.1111/j.1365-2486.2011.02516.x

Tang J, Baldocchi DD (2005). Spatial-temporal variation in soil respiration in an oak-grass savanna ecosystem in California and its partitioning into autotrophic and heterotrophic compo- 
nents. Biogeochemistry 73 (1): 183-207. - doi: 10.1007/s10533-004-5889-6

Tang JW, Baldocchi DD, Xu LK (2005). Tree photosynthesis modulates soil respiration on a diurnal time scale. Global Change Biology 11 (8): 1298-1304. - doi: 10.1111/j.1365-2486.20 05.00978.x

Tu LH, Hu TX, Zhang J, Li XW, Hu HL, Liu L, Xiao YL (2013). Nitrogen addition stimulates different components of soil respiration in a subtropical bamboo ecosystem. Soil Biology and Biochemistry 58: 255-264. - doi: 10.1016/j.soilbio.2012.12.005

Wan S, Luo Y (2003). Substrate regulation of soil respiration in a tallgrass prairie: results of a clipping and shading experiment. Global Biogeochemical Cycles 17 (2): 1054. - doi: 10.1029/2002 gb001971

Wan S, Luo Y, Wallace LL (2002). Changes in microclimate induced by experimental warming and clipping in tallgrass prairie. Global Change Biology 8 (8): 754-768. - doi: 10.1046/j.13652486.2002.00510.x

Wang C, Yang J (2007). Rhizospheric and heterotrophic components of soil respiration in six Chinese temperate forests. Global Change Biology 13 (1): 123-131. - doi: 10.1111/j.1365-2486.20 06.01291.x

Wang C, Gower ST, Wang Y, Zhao H, Yan P, Bond-Lamberty BP (2001). The influence of fire on carbon distribution and net primary production of boreal Larix gmelinii forests in north- eastern China. Global Change Biology 7 (6): 719-730. - doi: 10.1046/j.1354-1013.2001.0044 $1 . x$

Wang C, Yang J, Zhang Q (2006). Soil respiration in six temperate forests in China. Global Change Biology 12 (11): 2103-2114. - doi: 10.1111/j.13 65-2486.2006.01234.x

Wang W, Chen W, Wang S (2010). Forest soil respiration and its heterotrophic and autotrophic components: global patterns and responses to temperature and precipitation. Soil Biology and Biochemistry 42 (8): 1236-1244. - doi: 10.1016/ j.soilbio.2010.04.013

Wang C, Yang ZJ, Chen GS, Fan YX, Liu Q, Tian $H$ (2011). Characteristics of soil respiration in Phyllostachys edulis forest in Wanmulin Natural Reserve and related affecting factors. Chinese Journal of Applied Ecology 22 (5): 1212-1218. [in Chinese with English abstract]

Xiao F (2007). A study on the characteristics of carbon balance in Phyllostachys edulis plantation ecosystem. $\mathrm{PhD}$ thesis, Chinese Academy of Forestry, Beijing, China, pp. 63-90. [in Chinese with English abstract]

Xiao F, Fan S, Wang S, Guan F, Yu X, Shen Z (2010). Estimation of carbon balance in Moso bamboo forest and Chinese fir plantation ecosystem. Scientia Silvae Sinicae 46 (11): 59-65. [in Chinese with English abstract]

$\mathrm{Xu}$ M, Qi Y (2001). Soil-surface $\mathrm{CO}_{2}$ efflux and its spatial and temporal variations in a young ponderosa pine plantation in northern California.
Global Change Biology 7 (6): 667-677. - doi: 10.1046/j.1354-1013.2001.00435.x

Yan J, Wang Y, Zhou G, Zhang D (2006). Estimates of soil respiration and net primary production of three forests at different succession stages in South China. Global Change Biology 12 (5): 810-821. - doi: 10.1111/j.1365-2486.2006.0114 $1 . \mathrm{x}$

Yang YS, Chen GS, Guo JF, Xie JS, Wang XG (2007). Soil respiration and carbon balance in a subtropical native forest and two managed plantations. Plant Ecology 193 (1): 71-84. - doi: 10.1007/s11258-006-9249-6

Zheng Z-M, Yu G-R, Fu Y-L, Wang Y-S, Sun XM, Wang Y-H (2009). Temperature sensitivity of soil respiration is affected by prevailing climatic conditions and soil organic carbon content: a trans-China based case study. Soil Biology and Biochemistry 41 (7): 1531-1540. - doi: 10.1016/ j.soilbio.2009.04.013

Zhou G, Jiang P (2004). Density, storage and spatial distributbion of carbon in Phyllostachy pubescens forest. Scientia Silvae Sinicae 40 (6) 20-24. [in Chinese with English abstract]

Zhou GM (2006). Carbon storage, fixing and distribution in Moso bamboo forest ecosystems. Zhejiang University, Zhejiang, China, pp. 149. Zhou G, Jiang P, Xu Q (2010). Carbon sequestration and transform in bamboo ecosystem. Science Press, Beijing, China, pp. 105-137. 